\title{
Reappraisal of thienopyridine pretreatment in patients with non-ST elevation acute coronary syndrome: a systematic review and meta-analysis
}

\begin{abstract}
Objective To investigate the effect of pretreatment with $\mathrm{P}_{2} \mathrm{Y}_{12}$ receptor inhibitors compared with no pretreatment on efficacy and safety of treatment of non-ST elevation acute coronary syndrome (ACS).

Data sources Two reviewers independently searched Medline, Embase, Cochrane Controlled Trials, and BioMed Central databases for randomized placebo controlled trials and observational studies from August 2001 to March 2014.

Study eligibility Studies must have reported both all-cause mortality (primary efficacy endpoint) and major bleeding (safety endpoint) outcomes.

Data extraction Data on sample size, characteristics, drug dose and delay of administration, and outcomes were independently extracted and analyzed.

Data synthesis A random-effect model was applied. The analysis was performed (i) in all patients independently of the management strategy and (ii) only in patients undergoing percutaneous coronary intervention.

Results Of the 393 titles identified, seven (four randomized controlled trials, one observational analysis from a randomized controlled trial, and three observational studies) met the inclusion criteria. No study was identified for ticagrelor or cangrelor, and analyses were thus limited to thienopyridines. A total of 32383 non-ST elevation ACS patients were included, 18711 coming from randomized controlled trials. Of these, $55 \%$ underwent percutaneous coronary intervention $(\mathrm{PCl})$. Pretreatment was not associated with a significant lower risk of mortality in all patients
\end{abstract}

(odds ratio 0.90 ( $95 \%$ confidence interval 0.75 to 1.07 ), $P=0.24$ ), in particular when considering only the randomized controlled trials (odds ratio 0.90 ( 0.71 to 1.14$), P=0.39$ ). Similar results were observed in the cohort of patients undergoing $\mathrm{PCl}$. A significant $30-45 \%$ excess of major bleeding was consistently observed in all patients (odds ratio 1.32 (1.16 to 1.49), $\mathrm{P}<0.0001$ ) and in those undergoing $\mathrm{PCl}$, as well as in the subset analyses of randomized controlled trials of these two cohorts of patients. There was a reduction in major adverse cardiovascular events in the analysis of all patients (odds ratio 0.84 (0.72 to 0.98 ), $P=0.02$ ), driven by the old clopidogrel studies (CURE and CREDO), but the difference was not significant for the cohort of patients undergoing PCI. Stent thrombosis, stroke, and urgent revascularization did not differ between groups (pretreatment $v$ no pretreatment). The results were consistent for both thienopyridines and confirmed in sensitivity analyses.

Limitations Analysis was not performed on individual patient's data.

Conclusion In patients presenting with non-ST elevation ACS, pretreatment with thienopyridines is associated with no significant reduction of mortality but with a significant excess of major bleeding no matter the strategy adopted, invasive or not. Our results do not support a strategy of routine pretreatment in patients with non-ST elevation ACS.

\section{Introduction}

Non-ST elevation acute coronary syndrome (ACS) holds a significant burden in global healthcare systems with a one year incidence of more than $1.5 / 1000$ people. ${ }^{12}$ In real world management, two thirds of patients presenting with a non-ST 
elevation ACS have coronary angiography performed, a third have coronary stenting, and 7-10\% have coronary bypass surgery. ${ }^{2}$ Despite optimal evidence based treatment, these patients have worse mid-term and long term prognoses than patients with ST elevation ACS, with more frequent recurrent ischemic events and a twofold higher death rate at two years. ${ }^{3-5}$ Dual antiplatelet therapy with aspirin and a $\mathrm{P} 2 \mathrm{Y}_{12}$ receptor antagonist has been the cornerstone of the treatment of ACS, managed either medically or invasively. This is based on the single randomized CURE study, in which clopidogrel (300 mg pretreatment loading dose, $75 \mathrm{mg}$ maintenance dose) for a mean duration of nine months reduced ischemic endpoints by $20 \%$ in non-ST elevation ACS patients medically managed. ${ }^{6}$ In the CREDO trial, in which two thirds of enrolled patients had non-ST elevation ACS, significant superiority of pretreatment in patients undergoing percutaneous coronary intervention (PCI) was not demonstrated but was suggested only in subgroup analyses. ${ }^{78}$ These trials were conducted 15 years ago when clinical practice was different in many ways.

The rationale for pretreatment with oral $\mathrm{P} 2 \mathrm{Y}_{12}$ inhibitors is based on the need for a strong antiplatelet effect in non-ST elevation ACS patients scheduled for PCI,,${ }^{10}$ and the delay of action of these drugs, clopidogrel in particular, which provide a low and slow platelet inhibition in many patients. ${ }^{11}{ }^{12}$

Following the CURE and CREDO studies, clopidogrel pretreatment has been generalized for non-ST elevation ACS management with a Class I-B recommendation in the European and US guidelines, with the paradigm that "sooner is better." 1314 However, there has been no specific trial randomizing non-ST elevation ACS patients for clopidogrel pretreatment versus no pretreatment before routine catheterization as performed nowadays. Moreover, the time from hospital admission to catheterization has been considerably shortened in the past 10 years. ${ }^{15}$ The risk-benefit of pretreatment can now be reevaluated, considering the changes in practice and the accumulation of studies since the seminal publication of the CURE study allowing evaluation of low frequency but hard endpoints such as mortality and major bleeding. Indeed, pretreatment, a treatment administered before the coronary angiogram, may be detrimental in patients finally oriented towards coronary artery bypass graft surgery, which is performed within five days of clopidogrel loading in $87 \%$ of cases,${ }^{16}$ with associated higher perioperative transfusion rates of blood products and a twofold increase of reoperation for bleeding complications. ${ }^{17}$ Patients medically managed may also not benefit from pretreatment, especially when there is no significant coronary disease or an alternate diagnosis for the clinical presentation. Finally, a few randomized studies have questioned the risk-benefit of pretreatment in patients undergoing PCI, ${ }^{18}{ }^{19}$ and, in a meta-analysis performed in 37814 patients undergoing PCI (elective, urgent, or primary), we found no benefit of clopidogrel pretreatment on mortality.

The recent randomized ACCOAST trial demonstrated the absence of benefit of pretreatment with prasugrel in non-ST elevation ACS patients invasively managed. Moreover, there was hazard associated with pretreatment, suggesting an unfavorable risk-benefit of systematic pretreatment for patients with non-ST elevation ACS. ${ }^{20}$

We decided to evaluate the risk-benefit of routine pretreatment with $\mathrm{P} 2 \mathrm{Y}_{12}$ receptor inhibitors administered to patients with non-ST elevation ACS independently of the treatment strategy applied, medical or invasive. We included in the present meta-analysis not only randomized placebo controlled trials but also registries; we evaluated the global effect independently of revascularization (all patients included in the analysis) and the effect only in patients undergoing PCI, to evaluate potential differences according to the management strategy used.

\section{Methods}

We conducted a comparison of pretreatment with $\mathrm{P} 2 \mathrm{Y}_{12}$ inhibitors versus no pretreatment in patients with non-ST elevation ACS independently of the strategy applied (invasive or conservative), using a methodology described previously. ${ }^{21} 22$ We selected studies in which a majority $(>50 \%)$ of patients had non-ST elevation ACS. The main analysis was performed combining randomized controlled trial and observational studies together. Two separate analyses were performed: (i) for all patients included in the analysis (whatever the final treatment strategy, invasive or not) and (ii) for patients undergoing PCI revascularization after coronary angiography. Additional analyses were also performed for randomized controlled trials and observational studies considered separately.

Searches from Medline, Cochrane Controlled Trials Register, Embase, and BioMed Central databases were done from January 1980 through March 2014. Predefined search terms were: "non-ST-elevation acute coronary syndrome"; "clopidogrel" OR “prasugrel” OR "ticagrelor" OR "cangrelor" OR “elinogrel” AND "pretreatment" OR "loading dose" OR "preload" OR "timing" OR “upstream". No language restriction was used. Published articles, abstracts from selected major cardiology scientific meetings (American Heart Association, American College of Cardiology, European Society of Cardiology, and Transcatheter Cardiovascular Therapeutics) as references from reviews and selected articles were screened. Selection was done by two independent reviewers (ABA and MK).

\section{Eligibility criteria and data extraction}

Inclusion criteria were defined as follows: (i) studies including $>50 \%$ of patients with non-ST elevation ACS either medically treated or scheduled for catheterization; (ii) controlled comparison between pretreatment with $\mathrm{P} 2 \mathrm{Y}_{12}$ inhibitors and no pretreatment (that is, placebo or no treatment) through random or non-random allocation; (iii) data supplied on loading dose of $\mathrm{P} 2 \mathrm{Y}_{12}$ inhibitors; (iv) data available on at least mortality and bleeding. Full text articles and meeting abstracts of randomized controlled trials, registries, and pre-specified subgroups of randomized studies reporting data on pretreatment with $\mathrm{P} 2 \mathrm{Y}_{12}$ inhibitors were considered for analysis. Exclusion criteria were duplicate reports, the lack of control group, and ongoing studies. Extraction of data on study design and on clinical and safety outcomes was performed independently by two reviewers (ABA and $\mathrm{MK}$ ), and discrepancies were resolved by consensus.

\section{Endpoints definitions}

All cause mortality and major bleeding were the primary efficacy and safety endpoints, respectively. Secondary endpoints included major adverse cardiac events, myocardial infarction, stroke, and urgent revascularization (as defined in each study), and, when available, cardiovascular death, minor bleeding, and stent thrombosis (stent thrombosis recorded as definite or probable according to the criteria of the Academic Research Consortium) (table $\downarrow$ ). All bleeding were considered for the analysis of all patients, and non-coronary artery bypass graft surgery bleeding was considered for the analysis of patients undergoing PCI. Pretreatment was defined as the administration of a P2 $\mathrm{Y}_{12}$ inhibitor before catheterization or PCI. Each endpoint 
was taken at the shortest follow-up available in each study (table $\Downarrow$ ).

\section{Risk of bias}

We assessed the risk of bias within randomized clinical trials by analyzing the sequence generation, allocation concealment, blinding (of patients, investigators, and outcome assessment), incomplete outcome data, and selective outcome reporting. Each dimension was rated as low or high risk of bias, or unclear. ${ }^{23}$ The risk of bias within observational studies was assessed by analyzing selection of patients, comparability, and outcome; grading was done by two independent reviewers according the Newcastle-Ottawa Scale for registries (www.ohri.ca/programs/ clinical_epidemiology/oxford.htm).

\section{Statistical analysis}

Statistical analysis was conducted as follows: a random model was used and confirmed by the Mantel Hanszel fixed-effect model; the extent of heterogeneity between trials was assessed with the Q Cochran test (a P cut-off value of 0.1 was considered significant for heterogeneity) and $\mathrm{I}^{2}$ test for heterogeneity between subgroups was reported in each figure ${ }^{24}$; probability values were two tailed with $\mathrm{P}=0.05$ considered as significant. Odds ratios with $95 \%$ confidence intervals were calculated with the RevMan software version 5.0 (Cochrane Collaboration) and language $\mathrm{R}$ by using the meta-package. The main analysis was performed on all studies (randomized controlled trial and observational), for two groups: all patients with non-ST elevation ACS and the patients treated by PCI only. After assessment of heterogeneity, several sensitivity analyses were performed:

(1) Type of drug for randomized controlled trial

(2) Clopidogrel dose: pretreatment $<600 \mathrm{mg}$. Only one study included patients with clopidogrel $600 \mathrm{mg}$ loading dose only, ${ }^{25}$ and the analysis was done after exclusion of this study for assessment of the pretreatment effect of clopidogrel 300 mg loading dose

(3) Analysis that removed data from the CURE study from the analysis of patients who underwent PCI treatment. This was because the CURE study may not reflect contemporary practice (10 days of pretreatment with revascularization using plain balloon angioplasty or stent PCI).

Results for the main endpoints are reported in graphs by groups (all patients with non-ST elevation ACS and only those who underwent PCI), and in tables or text for secondary endpoints and sensitivity analyses.

This study was led and supported by the ACTION Study Group, an academic research organization based at Pitié-Salpêtrière Hospital (www.action-coeur.org). No other source of funding was obtained for this study.

\section{Results}

\section{Studies and patient characteristics}

Of the 393 abstracts identified from our search, seven studies published between 2001 and 2013 met the inclusion criteria with a total of 32383 patients.

Three were randomized controlled trials with a total of 18711 patients. The first study randomized non-ST elevation ACS patients for clopidogrel versus placebo, ${ }^{6}$ but the study protocol recommended a conservative strategy with medical management of the patients; subsequently only $43.8 \%$ of patients had a coronary angiogram performed and only $21.2 \%$ underwent
PCI. ${ }^{26}$ The second trial was performed with clopidogrel in elective PCI with most (67\%) patients being patients with non-ST elevation ACS ( $\mathrm{n}=1407$ patients), ${ }^{68}$ and randomization occurred mostly after the coronary angiogram (>90\% PCI) not corresponding really to the definition of pretreatment. The third study randomized non-ST elevation ACS patients with a significant rise of troponin to pretreatment with prasugrel or placebo started 2-48 hours before coronary angiography. ${ }^{20}$

One study was an observational pre-specified subgroup analysis of a randomized controlled trial ( $n=7523$ patients) for the question of clopidogrel pretreatment. ${ }^{27} 28$

Three included studies were observational ( $n=6149$ patients) for the question of pretreatment with clopidogrel. ${ }^{1825} 29$

No randomized study was found for pretreatment with any of the other $\mathrm{P} 2 \mathrm{Y}_{12}$ receptor antagonists (ticagrelor, elinogrel, or cangrelor). Thus the final analysis only included studies with clopidogrel (six studies) and prasugrel (one study). The flow chart of study selection is shown in figure $1 \Downarrow$. The observational studies, randomized controlled trials, and observational data from randomized controlled trials all had acceptable risks of bias (supplemental tables 1 and 2). Adjustments for the risk of confounding bias in the three observational studies were done by propensity score using a multivariable logistic regression model. Covariates that were tested included most important individual demographic characteristics, preprocedural clinical characteristics, and procedural variables. ${ }^{18} 2529$

\section{Main analysis: randomized controlled trials and observational studies}

For the analysis of all patients with non-ST elevation ACS, a total of 32383 patients were included. Of those, 17545 (54.5\%) underwent PCI and had been the subject of a separate analysis. Characteristics and definitions differed from one study to another and are summarized in the table $\Downarrow$. Four studies and one sub-study of PCI intervention had a $300 \mathrm{mg}$ loading dose of clopidogrel as pretreatment, ${ }^{6} 18262930$ one study had a $600 \mathrm{mg}$ loading dose, ${ }^{25}$ and in one substudy the clopidogrel loading dose was left to the discretion of the investigators but was $\geq 300 \mathrm{mg}$ in all cases. ${ }^{27}{ }^{28}$ In the ACCOAST study, the prasugrel pretreatment dose was $30 \mathrm{mg}$, completed at the time of PCI with another $30 \mathrm{mg}$ dose, compared with $60 \mathrm{mg}$ in the control group given only to PCI patients at the time of the revascularization procedure. $^{20}$

\section{All patients with non-ST elevation ACS Mortality}

Pretreatment with $\mathrm{P}_{2} \mathrm{Y}_{12}$ inhibitors was not associated with a significant reduction in death (any cause) (odds ratio $0.90(95 \%$ confidence interval 0.75 to 1.07 ), $\mathrm{P}=0.24$ ) (fig $2 \Downarrow$ ) nor in cardiovascular death (reported in only two randomized controlled trials and one PCI sub-study of a randomized controlled trial, ${ }^{6026}$ and one observational study, ${ }^{18} \mathrm{n}=16894$ patients) (odds ratio 0.72 (0.39 to 1.35 ), $\mathrm{P}=0.31, \mathrm{I}^{2}=44 \%$, $\mathrm{P}=0.17)$.

\section{Safety}

Pretreatment with $\mathrm{P} 2 \mathrm{Y}_{12}$ inhibitors was associated with a significant increase of major bleeding (odds ratio 1.32 (1.16 to 1.49), $\mathrm{P}<0.0001$ ) (fig $3 \Downarrow$ ).

Minor and any bleeding were exploratory endpoints, reported in 5 studies only ${ }^{6202529}$ and were both increased by pretreatment $(\mathrm{N}=24561$ patients: minor bleeding: $\mathrm{OR}=1.58$, 
95\% CI (1.09 to 2.29$), \mathrm{p}=0.02, \mathrm{I}^{2}=27 \%, \mathrm{p}=0.25$; any bleeding: $\mathrm{OR}=1.49,95 \% \mathrm{CI}$ ( 1.16 to 1.91$\left.), \mathrm{p}=0.002, \mathrm{I}^{2}=38 \%, \mathrm{p}=0.20\right)$.

\section{Secondary endpoints}

Major adverse cardiovascular events and myocardial infarction-Pretreatment with $\mathrm{P} 2 \mathrm{Y}_{12}$ inhibitors was associated with a significant reduction of major adverse cardiovascular events (odds ratio 0.84 ( 0.72 to 0.98 ), $\mathrm{P}=0.02$ ) but a non-significant reduction of myocardial infarction (odds ratio 0.81 (0.64 to 1.03 ), $\mathrm{P}=0.09, \mathrm{I}^{2}=58 \%, \mathrm{P}=0.09$ ).

Stroke-Pretreatment with $\mathrm{P} 2 \mathrm{Y}_{12}$ inhibitors was not associated with a reduction of stroke in the analysis of the four studies available for this endpoint ( $\mathrm{n}=19752$ patients) (odds ratio 0.86 (0.65 to 1.13), $\left.\mathrm{P}=0.27, \mathrm{I}^{2}=0 \%, \mathrm{P}=0.94\right) .{ }^{6} 82025$

Urgent revascularization-Pretreatment with $\mathrm{P}_{2} \mathrm{Y}_{12}$ inhibitors was not associated with a reduction of urgent revascularization in the analysis of the five studies available for this endpoint ( $\mathrm{n}=11397$ ) (odds ratio 0.79 (0.53 to 1.18$), \mathrm{P}=0.25, \mathrm{I}^{2}=0 \%$, $\mathrm{P}=0.87) .{ }^{818} 202529$

\section{Patients with non-ST elevation ACS undergoing $\mathrm{PCl}$ \\ Mortality}

Pretreatment with P2 $\mathrm{Y}_{12}$ inhibitors was not associated with a significant reduction in death (any cause) (odds ratio $0.83(0.59$ to 1.17), $\mathrm{P}=0.29)$ (fig $2 \Downarrow)$ nor in cardiovascular death $(\mathrm{n}=5730$ patients) (odds ratio 0.78 ( 0.28 to 2.14 ), $\mathrm{P}=0.63, \mathrm{I}^{2}=46 \%$, $\mathrm{P}=0.63)$.

\section{Safety}

Pretreatment with $\mathrm{P} 2 \mathrm{Y}_{12}$ inhibitors was associated with an increase of major bleeding (odds ratio 1.23 (1.00 to 1.50), $\mathrm{P}=0.048$ ) (fig $3 \Downarrow$ ), minor bleeding (1.37 (0.98 to 1.90$), \mathrm{P}=0.06$, $\left.\mathrm{I}^{2}=39 \%, \mathrm{P}=0.19\right)$, and any bleeding $(\mathrm{n}=13385$ patients, 1.37 (1.00 to 1.88$\left.), \mathrm{P}=0.048, \mathrm{I}^{2}=68 \%, \mathrm{P}=0.04\right)$ ).

\section{Secondary endpoints}

Major adverse cardiovascular events and myocardial infarction-Pretreatment with $\mathrm{P}_{2} \mathrm{Y}_{12}$ inhibitors was associated with a non-significant reduction of major adverse cardiovascular events (odds ratio 0.83 (0.69 to 1.01$), \mathrm{P}=0.06$ ) and myocardial infarction ( 0.77 ( 0.57 to 1.02 ), $\mathrm{P}=0.07, \mathrm{I}^{2}=68 \%, \mathrm{P}=0.04$ ).

Stent thrombosis was available in only two studies $(\mathrm{n}=3814$ patients). ${ }^{20}{ }^{25}$ The reduction of stent thrombosis after pretreatment with $\mathrm{P} 2 \mathrm{Y}_{12}$ inhibitors was not statistically significant (odds ratio 0.26 (0.04 to 1.57), $\mathrm{P}=0.14, \mathrm{I}^{2}=0 \%, \mathrm{P}=0.74$ ).

Stroke-Pretreatment with $\mathrm{P} 2 \mathrm{Y}_{12}$ inhibitors was not associated with a reduction of stroke in the analysis of the three studies available for this endpoint $(\mathrm{n}=5918)$ (odds ratio 0.77 (0.37 to 1.59), $\left.\mathrm{P}=0.48, \mathrm{I}^{2}=0 \%, \mathrm{P}=0.77\right){ }^{8}{ }^{2025}$

Urgent revascularization-Pretreatment with $\mathrm{P} 2 \mathrm{Y}_{12}$ inhibitors was associated with a reduction of urgent revascularization in the six studies available for the analysis only of patients undergoing PCI ( $\mathrm{n}=13395)$ (odds ratio 0.72 (0.52 to 1.00), $\left.\mathrm{P}=0.0488, \mathrm{I}^{2}=0 \%, \mathrm{P}=0.93\right),{ }^{18} 202526-30$ driven by the PCI subgroup of the CURE study, where the delay of pretreatment was 10 days on average.

\section{Randomized controlled trial analysis}

Results of the analysis restricted to the randomized controlled trials, including the two oldest studies with clopidogrel for all patients with non-ST elevation ACS, ${ }^{8} 26$ and for those who underwent PCI, ${ }^{68}$ and the recent ACCOAST study with prasugrel, ${ }^{20}$ are shown in figures $2-5 \Downarrow \Downarrow \Downarrow \Downarrow$. Globally, pretreatment with a $\mathrm{P} 2 \mathrm{Y}_{12}$ inhibitor was not associated with a reduction of all cause death in the analysis of all patients with non-ST elevation ACS ( $\mathrm{n}=18$ 410) (odds ratio 0.90 ( 0.71 to 1.14), $\mathrm{P}=0.39$ ) nor in the analysis restricted to those who underwent PCI ( $\mathrm{n}=4774)$ ( 0.92 ( 0.43 to 1.98$), \mathrm{P}=0.83)$. There was no reduction in major adverse cardiovascular events in both analyses. In contrast, major bleeding was significantly increased in the analysis of all patients, but not significantly in the analysis restricted to those who underwent PCI. One additional large randomized study with a subgroup analysis for the issue of clopidogrel pretreatment confirmed the absence of effect of pretreatment on mortality and major adverse cardiovascular events; major bleeding trended in the wrong direction in this study. ${ }^{27}$ There was no significant heterogeneity between trials for these endpoints. A modest effect on major adverse cardiovascular events was observed only in the old randomized clopidogrel studies but not in the more recent studies with clopidogrel $^{27}{ }^{28}$ or prasugrel. ${ }^{20}$ The deleterious safety impact of pretreatment was observed in all randomized studies with both drugs in the analysis of all patients with non-ST elevation, but was limited only to the more potent prasugrel in the analysis restricted to those who underwent PCI.

\section{Sensitivity analysis}

The sensitivity analyses (i) for clopidogrel $300 \mathrm{mg}$ loading dose only that excluded one study ( $\mathrm{n}=31342$ patients ${ }^{25}$ ) and (ii) for the patients who underwent PCI that excluded the CURE study $(n=16064 \text { patients })^{26}$ confirmed the main results of the previous analyses.

\section{Discussion Principal findings}

Pretreatment with $\mathrm{P} 2 \mathrm{Y}_{12}$ receptor antagonists (here thienopyridines, in the absence of data for the other drugs of the same class) is not associated globally with a favorable risk-benefit ratio in patients with non-ST elevation ACS. We were unable to show a benefit on mortality, but there was significant harm with a consistent excess of major bleeding across all the analyses. The modest reduction of major adverse cardiovascular events was driven by the old randomized studies of clopidogrel and the observational studies with clopidogrel, but not confirmed in the more recent randomized studies using clopidogrel..$^{20} 27$ Surprisingly, this effect on major adverse cardiovascular events was not driven by the cohort of patients who underwent percutaneous coronary intervention (PCI), in which we may have expected a particular benefit of pretreatment.

This work focused on patients with non-ST elevation ACS, independently of the management strategy and study drug used for pretreatment. Pretreatment with thienopyridines evaluated in more than 30000 patients presenting with non-ST elevation ACS was not associated with a reduction in all cause death. The $16 \%$ reduction in major adverse cardiovascular events was driven by a (non-significant) reduction of myocardial infarction-a diagnosis based on an elevation of cardiac markers which may be related to the initial event, the procedure of revascularization, or, more rarely, to a recurrent event. This reduction in major adverse cardiovascular events was balanced by a $27-43 \%$ excess of major bleeding depending on the analysis performed. Unfortunately, we were unable to define a subgroup that may benefit more from pretreatment, like the PCI cohort, which did not perform better in this analysis, alike in the recent 
ACCOAST study. ${ }^{20}$ Pretreatment in patients who finally underwent PCI was associated with little effect on major adverse cardiovascular events (17\% odds reduction, $\mathrm{P}=0.06)$ and an excess of major bleeding of a larger magnitude ( $23 \%$ odds excess, $\mathrm{P}=0.048$ ). This may explain the absence of effect observed on survival.

\section{Strengths and limitations of the meta-analysis and relations with other studies}

The concept of pretreatment was introduced for patients with non-ST elevation ACS after the CURE study. This study already showed a similar pattern (reduction in myocardial infarction and excess of major bleeding) but with a conservative management strategy and only $21 \%$ of patients undergoing PCI ( $82 \%$ of stents), for which only the control group had four weeks of clopidogrel $75 \mathrm{mg}$ after PCI. Consequently, CURE and its sub-study PCI-CURE did not really evaluate pretreatment, a treatment given before scheduled catheterization or PCI, but evaluated dual antiplatelet therapy in patients managed medically with a minority undergoing delayed catheterization, often several days after admission. The addition of more recent studies in this meta-analysis, including observational studies, allows better representation of contemporary practice with more frequent intervention and faster access to the catheterization laboratory, but also with more heterogeneity.

Examining the randomized studies only or all the studies did not modify the results, with a questionable risk-benefit balance and no impact on mortality despite an analysis performed on more than 32000 patients. The benefit observed on major adverse cardiovascular events in all patients with non-ST elevation ACS was driven by the observational studies and the two oldest randomized trials with clopidogrel. The results were at odds with the two recent randomized trials with clopidogrel ${ }^{27} 28$ and the one with prasugrel. ${ }^{20}$ It is difficult to sort out the benefit of pretreatment on major adverse cardiovascular events in the current era, with rapid access of patients to the catheterization laboratory and use of modern techniques of revascularization. Similar results were also found in patients with stable coronary artery disease who underwent elective PCI, where pretreatment with clopidogrel did not confer any ischemic benefit but significantly increased bleedings complications. ${ }^{31}$

Routine pretreatment is even more questionable nowadays, when patients reach the catheterization laboratory within 3-4 hours of admission, ${ }^{32-34}$ a delay that does not allow adequate platelet inhibition with clopidogrel in case of PCI but still exposes all patients, sometimes unnecessarily, to the risk of bleeding for several days after loading. The advantage of pretreatment is also less obvious with the availability of the new $\mathrm{P} 2 \mathrm{Y}_{12}$ antagonists that have a rapid onset of action, are indicated in non-ST elevation ACS, ${ }^{35}{ }^{36}$ and can be used after coronary artery disease has been diagnosed and the indication of PCI confirmed, as tested now in three large trials. ${ }^{36}{ }^{37}{ }^{20}$ Indeed, cangrelor, an intravenous $\mathrm{P}_{2} \mathrm{Y}_{12}$ antagonist of immediate action, showed superiority over clopidogrel in patients undergoing PCI with an excellent safety profile. ${ }^{37}$ Prasugrel, which has a faster and stronger antiplatelet effect than clopidogrel, also showed the valididy of a strategy of later administration once the coronary anatomy has been defined. ${ }^{20}{ }^{36}$

We acknowledge several limitations to our study. As with any meta-analysis, several biases may have interfered with the final results, for which precautions and limitations have been described elsewhere. ${ }^{21}$ Confidence intervals are wide, and definite conclusion cannot been made solely on point estimates without taking the variability about them into consideration. In addition, confounding by indication, although controlled, cannot be excluded in registries, and we found significant heterogeneity between observational studies on clopidogrel, which may limit conclusions. This heterogeneity might be due to differences in clinical presentation (non-ST elevation ACS at low or higher risk), in bleeding risk, and in the dose and timing of clopidogrel pretreatment (table $\Downarrow$ ). However, the global results using all studies available were confirmed in the more robust subgroup of randomized controlled trials and the pre-specified sensitivity analyses.

Another limitation relates to the $300 \mathrm{mg}$ clopidogrel loading dose, where we cannot exclude the possibility that a higher dose, which is known to confer faster and stronger platelet inhibition, ${ }^{38}$ would have given a different result. However, the only study in this meta-analysis that used a $600 \mathrm{mg}$ loading dose did not favor pretreatment, ${ }^{25}$ and the CURRENT study did not confirm the superiority of $600 \mathrm{mg}$ over $300 \mathrm{mg}$ of clopidogrel in the global management of non-ST elevation ACS. ${ }^{32}$ Because no data are available for ticagrelor, conclusions cannot be drawn for this drug. Postponing treatment to after the coronary angiogram is certainly acceptable in patients reaching the catheterization laboratory within 48 hours after admission, as in the studies that tested this hypothesis, ${ }^{27}{ }^{28}$ but not in patients with longer waiting periods or for emergent cases (ST-elevation-like patients) who were not enrolled in these studies.

\section{Conclusions and policy implications}

In conclusion, our meta-analysis shows that in patients with non-ST elevation ACS, pretreatment with thienopyridines is not associated with a lower risk of mortality globally or more specifically in patients undergoing PCI. The reduction of ischemic endpoints is modest and counterbalanced by an increase in major bleeding, no matter the final management strategy with or without PCI. The concept of systematic and immediate pretreatment with $\mathrm{P} 2 \mathrm{Y}_{12}$ antagonists in patients admitted with non-ST elevation ACS needs to be reconsidered.

Contributors: GM had the idea, then planned and conducted the study with $A B A$. ABA and MK performed the literature search and selected studies, $A B A$ and $M K$ extracted study data, $A B A$ and $M C$ assessed risk of bias, performed the statistical analysis, and wrote the manuscript. All authors assisted in formulation of the research question, assessed quality of evidence, contributed to and developed the final manuscript. ABA, GM, MC, and MK had full access to all of the data.

Funding: No external source of funding. The study was led by the ACTION Study Group (www.action-coeur.org).

Competing interests: All authors have completed the ICMJE uniform disclosure form at http://www.icmje.org/coi_disclosure.pdf and declare: no support from any organisation for the submitted work; no financial relationships with any organisations that might have an interest in the submitted work in the previous three years; no other relationships or activities that could appear to have influenced the submitted work.

GM has received consulting fees from Bayer, Boehringer-Ingelheim, CFR, Europa, GLG, Iroko Cardio International, Lead-Up, LLC, Luminex, Mc Kinsey, Remedica, Servier, TIMI Group, WebMD, and Wolters; consulting fees and grant support from Bristol-Myers Squibb, AstraZeneca, Biotronik, Eli Lilly, The Medicines Company, Medtronic, Menarini, Sanofi-Aventis, Pfizer, and Accumetrics; and grant support from Abbott Vascular, Daiichi-Sankyo, Nanospheres, and Stentys. JPC has received research grants from Bristol-Myers Squibb, Sanofi-Aventis, Eli Lilly, Guerbet Medical, Medtronic, Boston Scientific, Cordis, Stago, Centocor, Fondation de France, INSERM, Federation Francaise de Cardiologie, and Société Française de Cardiologie; consulting fees from Sanofi-Aventis, Eli Lilly, and Bristol-Myers Squibb; and lecture fees from 


\section{What is already known on this topic}

Pretreatment with $\mathrm{P}_{2} \mathrm{Y}_{12}$ inhibitors for non-ST elevation acute coronary syndrome (ACS) patients has a class I-B recommendation, based on old studies done before the contemporary routine and early access to coronarography

Recent randomized and observational studies have questioned the risk-benefit of pretreatment in patients undergoing percutaneous coronary intervention $(\mathrm{PCl})$

\section{What this study adds}

This systematic review and meta-analysis shows that in patients with non-ST elevation ACS, pretreatment with thienopyridines is not associated with a lower risk of mortality globally or more specifically in patients undergoing $\mathrm{PCl}$. The reduction of ischemic endpoints is modest and counterbalanced by an increase in major bleeding, no matter the final management strategy, with or without $\mathrm{PCl}$

The concept of systematic and immediate pretreatment with $\mathrm{P}_{2} \mathrm{Y}_{12}$ antagonists in patients admitted with non-ST elevation ACS needs to be reconsidered in daily practice and in guidelines

Bristol-Myers Squibb, Sanofi-Aventis, and Eli Lilly. ABA has received research grants from Daiichi-Sankyo, Eli Lilly, Fédération Française de Cardiologie and Société Française de Cardiologie and lecture fees from AstraZeneca, Servier, and Daiichi-Sankyo. JS reports receiving research grants from Sanofi-Aventis, Daiichi-Sankyo, Eli Lilly, Brahms, INSERM, Fédération Française de Cardiologie and Société Française de Cardiologie; consulting fees from Daiichi-Sankyo, Eli Lilly and speaker honoraria from AstraZeneca, Daiichi Sankyo, Eli Lilly, Iroko Cardio and Servier. SAO'C has received grants from A Menarini and the European Society of Cardiology. MC has received research grants from Bristol-Myers Squibb, AstraZeneca, Bayer, Haute Autorité de Santé; consulting fees from Bayer, Bristol-Myers Squibb; and speaker honoraria from Bristol-Myers Squibb.

Ethical approval: Not required

Transparency: The lead author (the manuscript's guarantor) affirms that the manuscript is an honest, accurate, and transparent account of the study being reported; that no important aspects of the study have been omitted; and that any discrepancies from the study as planned (and, if relevant, registered) have been explained.

Data sharing: No additional data available.

1 Fox KA, Eagle KA, Gore JM, Steg PG, Anderson FA. The global registry of acute coronary events, 1999 to 2009—grace. Heart 2010;96:1095-101.

2 Mandelzweig L, Battler A, Boyko V, Bueno H, Danchin N, Filippatos G, et al. The second Euro Heart Survey on acute coronary syndromes: characteristics, treatment, and outcome of patients with ACS in Europe and the Mediterranean basin in 2004. Eur Heart $J$ 2006;27:2285-93.

3 Savonitto S, Ardissino D, Granger CB, Morando G, Prando MD, Mafrici A, et al. Prognostic value of the admission electrocardiogram in acute coronary syndromes. JAMA 1999;281:707-13.

4 Yeh RW, Sidney S, Chandra M, Sorel M, Selby JV, Go AS. Population trends in the incidence and outcomes of acute myocardial infarction. N Engl J Med 2010;362:2155-65.

5 Terkelsen CJ, Lassen JF, Norgaard BL, Gerdes JC, Jensen T, Gotzsche LB, et al. Mortality rates in patients with ST-elevation vs. non-ST-elevation acute myocardial infarction: observations from an unselected cohort. Eur Heart J 2005;26:18-26.

6 Yusuf S, Zhao F, Mehta SR, Chrolavicius S, Tognoni G, Fox KK. Effects of clopidogrel in addition to aspirin in patients with acute coronary syndromes without ST-segment elevation. N Engl J Med 2001;345:494-502.

7 Steinhubl SR, Berger PB, Brennan DM, Topol EJ. Optimal timing for the initiation of pre-treatment with $300 \mathrm{mg}$ clopidogrel before percutaneous coronary intervention. J Am Coll Cardiol 2006:47:939-43.

8 Steinhubl SR, Berger PB, Mann JT 3rd, Fry ET, DeLago A, Wilmer C, et al. Early and sustained dual oral antiplatelet therapy following percutaneous coronary intervention: a randomized controlled trial. JAMA 2002;288:2411-20.

9 Cuisset T, Frere C, Quilici J, Barbou F, Morange PE, Hovasse T, et al. High post-treatment platelet reactivity identified low-responders to dual antiplatelet therapy at increased risk of recurrent cardiovascular events after stenting for acute coronary syndrome. J Thromb Haemost 2006;4:542-9.

10 Matetzky S, Shenkman B, Guetta V, Shechter M, Beinart R, Goldenberg I, et al. Clopidogrel resistance is associated with increased risk of recurrent atherothrombotic events in patients with acute myocardial infarction. Circulation 2004;109:3171-5.

11 Gurbel PA, Bliden KP, Hiatt BL, O'Connor CM. Clopidogrel for coronary stenting: Response variability, drug resistance, and the effect of pretreatment platelet reactivity. Circulation 2003;107:2908-13.

12 Bellemain-Appaix A, Montalescot G, Silvain J, Barthelemy O, Beygui F, Collet JP, et al. Slow response to clopidogrel predicts low response. J Am Coll Cardiol 2010;55:815-22.

13 Hamm CW, Bassand JP, Agewall S, Bax J, Boersma E, Bueno H, et al. ESC Guidelines for the management of acute coronary syndromes in patients presenting without persisten ST-segment elevation: The Task Force for the management of acute coronary syndromes (ACS) in patients presenting without persistent ST-segment elevation of the European Society of Cardiology (ESC). Eur Heart J 2011;32:2999-3054.

14 Jneid H, Anderson JL, Wright RS, Adams CD, Bridges CR, Casey DE Jr, et al. 2012 ACCF/AHA focused update of the guideline for the management of patients with unstable angina/Non-ST-elevation myocardial infarction (updating the 2007 guideline and replacing the 2011 focused update): a report of the American College of Cardiology
Foundation/American Heart Association Task Force on practice guidelines. Circulation 2012;126:875-910

15 Navarese EP, Gurbel PA, Andreotti F, Tantry U, Jeong YH, Kozinski ME, et al. Optimal timing of coronary invasive strategy in non-st-segment elevation acute coronary syndromes: A systematic review and meta-analysis. Ann Intern Med 2013;158:261-70.

16 Mehta RH, Roe MT, Mulgund J, Ohman EM, Cannon CP, Gibler WB, et al. Acute clopidogrel use and outcomes in patients with non-st-segment elevation acute coronary syndromes undergoing coronary artery bypass surgery. J Am Coll Cardiol 2006;48:281-6.

17 Biancari F, Airaksinen KE, Lip GY. Benefits and risks of using clopidogrel before coronary artery bypass surgery: systematic review and meta-analysis of randomized trials and observational studies. J Thorac Cardiovasc Surg 2012;143:665-75

18 Assali AR, Salloum J, Sdringola S, Moustapha A, Ghani M, Hale S, et al. Effects of clopidogrel pretreatment before percutaneous coronary intervention in patients treated with glycoprotein llb/llla inhibitors (abciximab or tirofiban). Am J Cardiol 2001;88:884-6, A886.

19 Di Sciascio G, Patti G, Pasceri V, Gatto L, Colonna G, Montinaro A. Effectiveness of in-laboratory high-dose clopidogrel loading versus routine pre-load in patients undergoing percutaneous coronary intervention: results of the ARMYDA-5 PRELOAD (Antiplatelet therapy for Reduction of MYocardial Damage during Angioplasty) randomized trial. J Am Coll Cardiol 2010;56:550-7.

20 Montalescot G, Bolognese L, Dudek D, Goldstein P, Hamm C, Tanguay JF, et al. Pretreatment with prasugrel in non-ST-segment elevation acute coronary syndromes. $N$ Engl J Med 2013;369:999-1010.

21 Bellemain-Appaix A, O'Connor SA, Silvain J, Cucherat M, Beygui F, Barthelemy O, et al. Association of clopidogrel pretreatment with mortality, cardiovascular events, and major bleeding among patients undergoing percutaneous coronary intervention: a systematic review and meta-analysis. JAMA 2012;308:2507-16.

22 Bellemain-Appaix A, Brieger D, Beygui F, Silvain J, Pena A, Cayla G, et al. New p2y12 inhibitors versus clopidogrel in percutaneous coronary intervention: a meta-analysis. $J$ Am Coll Cardiol 2010;56:1542-51.

23 Higgins JP, Altman DG, Gotzsche PC, Juni P, Moher D, Oxman AD, et al. The Cochrane Collaboration's tool for assessing risk of bias in randomised trials. BMJ 2011;343:d5928.

4 Higgins JP, Thompson SG, Deeks JJ, Altman DG. Measuring inconsistency in meta-analyses. BMJ 2003;327:557-60

25 Feldman DN, Fakorede F, Minutello RM, Bergman G, Moussa I, Wong SC. Efficacy of high-dose clopidogrel treatment $(600 \mathrm{mg})$ less than two hours before percutaneous coronary intervention in patients with non-ST-segment elevation acute coronary syndromes. Am J Cardiol 2010;105:323-32.

26 Mehta SR, Yusuf S, Peters RJ, Bertrand ME, Lewis BS, Natarajan MK, et al. Effects of pretreatment with clopidogrel and aspirin followed by long-term therapy in patients undergoing percutaneous coronary intervention: The PCI-CURE study. Lancet 2001;358:527-33.

27 Stone GW, White HD, Ohman EM, Bertrand ME, Lincoff AM, McLaurin BT, et al. Bivalirudin in patients with acute coronary syndromes undergoing percutaneous coronary intervention: a subgroup analysis from the Acute Catheterization and Urgent Intervention Triage strategy (ACUITY) trial. Lancet 2007:369:907-19.

28 White HD, Ohman EM, Lincoff AM, Bertrand ME, Colombo A, McLaurin BT, et al. Safety and efficacy of bivalirudin with and without glycoprotein Ilb/llla inhibitors in patients with acute coronary syndromes undergoing percutaneous coronary intervention 1-year results from the ACUITY (Acute Catheterization and Urgent Intervention Triage strategy) trial. $J$ Am Coll Cardiol 2008:52:807-14.

29 Chan AW, Moliterno DJ, Berger PB, Stone GW, DiBattiste PM, Yakubov SL, et al. Triple antiplatelet therapy during percutaneous coronary intervention is associated with improved outcomes including one-year survival: Results from the Do Tirofiban and ReoProGive Similar Efficacy Outcome Trial (TARGET). J Am Coll Cardiol 2003;42:1188-95.

30 Steinhubl SR, Ellis SG, Wolski K, Lincoff AM, Topol EJ. Ticlopidine pretreatment before coronary stenting is associated with sustained decrease in adverse cardiac events: Data from the Evaluation of Platelet llb/llla Inhibitor for Stenting (EPISTENT) Trial. Circulation 2001;103:1403-9.

31 Widimsky P, Motovska Z, Simek S, Kala P, Pudil R, Holm F, et al. Clopidogrel pre-treatment in stable angina: for all patients $>6 \mathrm{~h}$ before elective coronary angiography or only for angiographically selected patients a few minutes before $\mathrm{PCI}$ ? A randomized multicentre trial PRAGUE-8. Eur Heart J 2008;29:1495-503.

32 Mehta SR, Tanguay JF, Eikelboom JW, Jolly SS, Joyner CD, Granger CB, et al. Double-dose versus standard-dose clopidogrel and high-dose versus low-dose aspirin in individuals undergoing percutaneous coronary intervention for acute coronary syndromes (CURRENT-OASIS 7): a randomised factorial trial. Lancet 2010;376:1233-43.

33 Montalescot G, Cayla G, Collet JP, Elhadad S, Beygui F, Le Breton H, et al. Immediate vs delayed intervention for acute coronary syndromes: a randomized clinical trial. JAMA 2009;302:947-54

34 Stone GW, McLaurin BT, Cox DA, Bertrand ME, Lincoff AM, Moses JW, et al. Bivalirudin for patients with acute coronary syndromes. N Engl J Med 2006;355:2203-16.

35 Wallentin L, Becker RC, Budaj A, Cannon CP, Emanuelsson H, Held C, et al. Ticagrelor versus clopidogrel in patients with acute coronary syndromes. N Engl J Med 2009;361:1045-57. 
36 Wiviott SD, Braunwald E, McCabe CH, Montalescot G, Ruzyllo W, Gottlieb S, et al. Prasugrel versus clopidogrel in patients with acute coronary syndromes. N Engl J Med 2007;357:2001-15

37 Bhatt DL, Stone GW, Mahaffey KW, Gibson CM, Steg PG, Hamm CW, et al. Effect of platelet inhibition with cangrelor during pci on ischemic events. N Engl J Med 2013;368:1303-13.

38 Montalescot G, Sideris G, Meuleman C, Bal-dit-Sollier C, Lellouche N, Steg PG, et al. A randomized comparison of high clopidogrel loading doses in patients with non-st-segmen elevation acute coronary syndromes: the ALBION (Assessment of the Best Loading Dose of Clopidogrel to Blunt Platelet Activation, Inflammation and Ongoing Necrosis) trial. $J$ Am Coll Cardiol 2006;48:931-8.

39 Dorler J, Edlinger M, Alber HF, Altenberger J, Benzer W, Grimm G, et al. Clopidogrel pre-treatment is associated with reduced in-hospital mortality in primary percutaneous coronary intervention for acute ST-elevation myocardial infarction. Eur Heart J 2011:32:2954-61.

40 Fefer P, Hod H, Hammerman H, Segev A, Beinart R, Boyko V, et al. Usefulness of pretreatment with high-dose clopidogrel in patients undergoing primary angioplasty for ST-elevation myocardial infarction. Am J Cardiol 2009;104:514-8.

41 Sabatine MS, Cannon CP, Gibson CM, Lopez-Sendon JL, Montalescot G, Theroux P, et al. Effect of clopidogrel pretreatment before percutaneous coronary intervention in patients with ST-elevation myocardial infarction treated with fibrinolytics: the PCI-CLARITY study. JAMA 2005;294:1224-32.

42 Zeymer U, Arntz HR, Darius H, Huber K, Senges J. Efficacy and safety of clopidogrel 600 $\mathrm{mg}$ administered pre-hospitally to improve primary percutaneous coronary intervention in patients with acute myocardial infarction (CIPAMI): study rationale and design. Cardiology 2007;108:265-72.

43 Kastrati A, Mehilli J, Neumann FJ, Dotzer F, ten Berg J, Bollwein H, et al. Abciximab in patients with acute coronary syndromes undergoing percutaneous coronary intervention after clopidogrel pretreatment: the ISAR-REACT 2 randomized trial. JAMA 2006;295:1531-8

44 Kastrati A, Mehilli J, Schuhlen H, Dirschinger J, Dotzer F, ten Berg JM, et al. A clinical trial of abciximab in elective percutaneous coronary intervention after pretreatment with clopidogrel. N Engl J Med 2004:350:232-8.

45 Wang TY, White JA, Tricoci P, Giugliano RP, Zeymer U, Harrington RA, et al. Upstream clopidogrel use and the efficacy and safety of early eptifibatide treatment in patients with acute coronary syndrome: an analysis from the Early Glycoprotein Ilb/llla Inhibition in Patients with Non-ST-Segment Elevation Acute Coronary Syndrome (EARLY ACS) trial. Circulation 2011:123:722-30.

46 Bonello L, Lemesle G, De Labriolle A, Roy P, Steinberg DH, Pinto Slottow TL, et al. Impact of a 600 -mg loading dose of clopidogrel on 30-day outcome in unselected patients undergoing percutaneous coronary intervention. Am J Cardiol 2008;102:1318-22.

47 Cuisset T, Frere C, Quilici J, Morange PE, Nait-Saidi L, Carvajal J, et al. Benefit of a $600-\mathrm{mg}$ loading dose of clopidogrel on platelet reactivity and clinical outcomes in patients with non-ST-segment elevation acute coronary syndrome undergoing coronary stenting. J Am Coll Cardiol 2006:48:1339-45.

48 Jung JH, Min PK, Lee SH, Sung CW, Choi S, Cho JR, et al. Clopidogrel pretreatment before primary percutaneous coronary stenting in patients with acute ST-segment elevation myocardial infarction: comparison of high loading dose $(600 \mathrm{mg})$ versus low loading dose (300 mg). Coron Artery Dis 2009;20:150-4.

49 Mangiacapra F, Muller O, Ntalianis A, Trana C, Heyndrickx GR, Bartunek J, et al. Comparison of 600 versus $300-\mathrm{mg}$ clopidogrel loading dose in patients with ST-segmen elevation myocardial infarction undergoing primary coronary angioplasty. Am J Cardiol 2010;106:1208-11

50 Lin GM, Li YH, Chu KM, Han CL.Standard versus high loading doses of clopidogrel in Asian patients with ST-segment elevation myocardial infarction undergoing percutaneous coronary intervention: insights from the Korea Acute Myocardial Infarction Registry. Am Heart J 2011:162:e17.

51 Patti G, Colonna G, Pasceri V, Pepe LL, Montinaro A, Di Sciascio G. Randomized trial of high loading dose of clopidogrel for reduction of periprocedural myocardial infarction in patients undergoing coronary intervention: results from the ARMYDA-2 (Antiplatelet therapy for Reduction of MYocardial Damage during Angioplasty) study. Circulation 2005;111:2099-106.

52 Yong G, Rankin J, Ferguson L, Thom J, French J, Brieger D, et al. Randomized trial comparing 600- with 300-mg loading dose of clopidogrel in patients with non-ST elevation acute coronary syndrome undergoing percutaneous coronary intervention: results of the Platelet Responsiveness to Aspirin and Clopidogrel and Troponin Increment after Coronary intervention in Acute coronary Lesions (PRACTICAL) Trial. Am Heart J 2009;157:60.e1-9.

53 Mangiacapra F, Patti G, Barbato E, Orlic D, Peace AJ, D'Ambrosio A, et al. Antiplatelet effect of 600 - and $300-\mathrm{mg}$ loading doses of clopidogrel in patients undergoing primary percutaneous coronary intervention for ST-segment elevation myocardial infarction: an analysis of the ARMYDA-6 MI (Antiplatelet therapy for Reduction of MYocardial Damage during Angioplasty-Myocardial Infarction) Study. Int J Cardiol 2012:160:213-4

54 Song PS, Hahn JY, Song YB, Choi JH, Choi SH, Kang GH, et al. Effects of $600 \mathrm{mg}$ versus $300 \mathrm{mg}$ loading dose of clopidogrel in Asian patients with ST-segment elevation myocardial infarction undergoing primary percutaneous coronary intervention: long-term follow-up study. Yonsei Med J 2012;53:906-14

55 Di Sciascio G, Patti G, Pasceri V, Gatto L, Colonna G, Montinaro A. Effectiveness of in-laboratory high-dose clopidogrel loading versus routine pre-load in patients undergoing percutaneous coronary intervention: results of the ARMYDA-5 PRELOAD (Antiplatelet therapy for Reduction of MYocardial Damage during Angioplasty) randomized trial. J Am Coll Cardiol 2010;56:550-7

56 Mahmoudi M, Syed AI, Ben-Dor I, Gonzalez M, Maluenda G, Gaglia MA Jr, et al. Safety and efficacy of clopidogrel reloading in patients on chronic clopidogrel therapy who present with an acute coronary syndrome and undergo percutaneous coronary intervention. $A m$ $J$ Cardiol 2011;107:1779-82.

57 Patti G, Pasceri V, Mangiacapra F, Colonna G, Vizzi V, Ricottini E, et al. Efficacy of clopidogrel reloading in patients with acute coronary syndrome undergoing percutaneous coronary intervention during chronic clopidogrel therapy (from the Antiplatelet therapy for Reduction of MYocardial Damage during Angioplasty [ARMYDA-8 RELOAD-ACS] trial). Am J Cardiol 2013:112:162-8.

58 Ebrahimi R, Dyke C, Mehran R, Manoukian SV, Feit F, Cox DA, et al. Outcomes following pre-operative clopidogrel administration in patients with acute coronary syndromes undergoing coronary artery bypass surgery: the ACUITY (Acute Catheterization and Urgent Intervention Triage strategY) trial. J Am Coll Cardiol 2009;53:1965-72.

59 Dery JP, Campbell ME, Mathias J, Pieper KS, Harrington RA, Madan M, et al Complementary effects of thienopyridine pretreatment and platelet glycoprotein iib/iiia integrin blockade with eptifibatide in coronary stent intervention; results from the ESPRIT trial. Catheter Cardiovasc Interv 2007;70:43-50.

60 Koul S, Smith JG, Schersten F, James S, Lagerqvist B, Erlinge D. Effect of upstream clopidogrel treatment in patients with ST-segment elevation myocardial infarction undergoing primary percutaneous coronary intervention. Eur Heart J 2011;32:2989-97.

61 Amin AP, Kennedy KF, Pencina M, Berger P, Piana RN, Lopez J, et al Effect of clopidogrel pretreatment on ischemic complications of percutaneous coronary intervention among bivalirudin-treated patients (from the EVENT registry). Am J Cardiol 2011;107:1751-6.

62 Davlouros PA, Arseniou A, Hahalis G, Chiladakis J, Mazarakis A, Damelou A, et al. Timing of clopidogrel loading before percutaneous coronary intervention in clopidogrel-naive patients with stable or unstable angina: a comparison of two strategies. Am Heart $J$ 2009;158:585-91.

63 Saw J, Lincoff AM, DeSmet W, Betriu A, Rutsch W, Wilcox RG, et al. Lack of clopidogrel pretreatment effect on the relative efficacy of bivalirudin with provisional glycoprotein Ilb/llla blockade compared to heparin with routine glycoprotein Ilb/llla blockade: a REPLACE-2 substudy. J Am Coll Cardiol 2004;44:1194-9.

64 Szuk T, Gyongyosi M, Homorodi N, Kristof E, Kiraly C, Edes IF, et al. Effect of timing of clopidogrel administration on 30-day clinical outcomes: $300-\mathrm{mg}$ loading dose immediately after coronary stenting versus pretreatment 6 to 24 hours before stenting in a large unselected patient cohort. Am Heart J 2007;153:289-95.

\section{Accepted: 17 September 2014}

\section{Cite this as: BMJ 2014;349:g6269}

This is an Open Access article distributed in accordance with the Creative Commons Attribution Non Commercial (CC BY-NC 3.0) license, which permits others to distribute, remix, adapt, build upon this work non-commercially, and license their derivative works on different terms, provided the original work is properly cited and the use is non-commercial. See: http://creativecommons.org/licenses/by-nc/3.0/. 


\section{Table}

\begin{tabular}{|c|c|c|c|c|c|c|c|c|}
\hline \multirow[b]{2}{*}{ Study } & \multirow[b]{2}{*}{ Type of trial } & \multicolumn{2}{|c|}{ No (\%) of study patients } & \multirow[b]{2}{*}{ Pretreatment } & \multirow[b]{2}{*}{ No pretreatment } & \multirow[b]{2}{*}{$\begin{array}{l}\text { Endpoints } \\
\text { MACEs }\end{array}$} & \multirow[b]{2}{*}{$\begin{array}{l}\text { Bleeding } \\
\text { definitions }\end{array}$} & \multirow[b]{2}{*}{ Follow-up } \\
\hline & & $\begin{array}{c}\text { Non-ST } \\
\text { elevation ACS }\end{array}$ & $\begin{array}{l}\text { Undergoing } \\
\text { PCl }\end{array}$ & & & & & \\
\hline \multicolumn{9}{|c|}{ Registries (for clopidogrel only) } \\
\hline $\begin{array}{l}\text { Feldman et al } \\
2010^{25}\end{array}$ & $\begin{array}{l}\text { Retrospective } \\
\text { registry of } \\
\text { cohort }\end{array}$ & $1041 / 1041(100)$ & $\begin{array}{c}1041 / 1041 \\
(100)\end{array}$ & $\begin{array}{c}75 \mathrm{mg} \mathrm{MD} \text { for } \geq 5 \text { days or } \\
300 \mathrm{mg} \mathrm{LD} \text { for } \geq 12 \text { hours } \\
\text { or } \\
600 \mathrm{mg} \text { LD for } \geq 2 \text { hours }\end{array}$ & $\begin{array}{c}600 \mathrm{mg} \text { LD for }<2 \\
\text { hours or } \\
600 \mathrm{mg} \mathrm{LD} \text { on table }\end{array}$ & $\begin{array}{l}\text { Death, MI, } \\
\text { UTVR, stroke }\end{array}$ & $\begin{array}{c}\text { Major } \geq 4 \mathrm{~g} / \mathrm{dL} \\
\mathrm{Hb} \\
\text { Minor } 2-<4 \\
\mathrm{~g} / \mathrm{dL}\end{array}$ & $\begin{array}{c}\text { In hospital, } 1 \\
\text { year }\end{array}$ \\
\hline $\begin{array}{l}\text { Chan et al } \\
2003^{29}\end{array}$ & $\begin{array}{l}\text { Retrospective } \\
\text { registry of } \\
\text { cohort }\end{array}$ & $\begin{array}{c}2763 / 4809 \\
(57.4)\end{array}$ & $\begin{array}{c}4809 / 4809 \\
(100)\end{array}$ & $\begin{array}{c}300 \mathrm{mg} \text { pre- } \mathrm{PCl}: \\
56.6 \%<2 \text { hours } \\
27.2 \% 2-6 \text { hours } \\
16.2 \%>6 \text { hours } \\
\text { (mean } 2.1 \text { hours) }\end{array}$ & $\begin{array}{c}300 \mathrm{mg} \text { LD } \\
\text { immediately after } \\
\text { PCl }\end{array}$ & $\begin{array}{l}\text { Death, MI, } \\
\text { UTVR }\end{array}$ & $\begin{array}{l}\text { TIMI major or } \\
\text { minor } \\
\text { bleeding }\end{array}$ & $\begin{array}{l}30 \text { days, } 6 \\
\text { months, } 1 \\
\text { year (death } \\
\text { only) }\end{array}$ \\
\hline $\begin{array}{l}\text { Assali et al } \\
2008^{18}\end{array}$ & $\begin{array}{l}\text { Retrospective } \\
\text { registry of } \\
\text { cohort }\end{array}$ & 205/299 (68.6) & 299/299 (100) & $\begin{array}{c}75 \mathrm{mg} \text { MD within } 5 \text { days } \\
\text { or } \\
300 \mathrm{mg} \text { LD in morning } \\
\text { plus } \\
\text { glycoprotein llb/llla } \\
\text { inhibitor }\end{array}$ & $\begin{array}{c}300 \mathrm{mg} \text { LD } \\
\text { immediately after } \\
\text { PCl }\end{array}$ & $\begin{array}{l}\text { CV death, MI, } \\
\text { UTVR }\end{array}$ & $\begin{array}{c}\text { IC, } \\
\text { transfusion, } \\
\text { hemodynamic } \\
\text { compromise }\end{array}$ & In hospital \\
\hline
\end{tabular}

Randomized controlled trials (RCT)

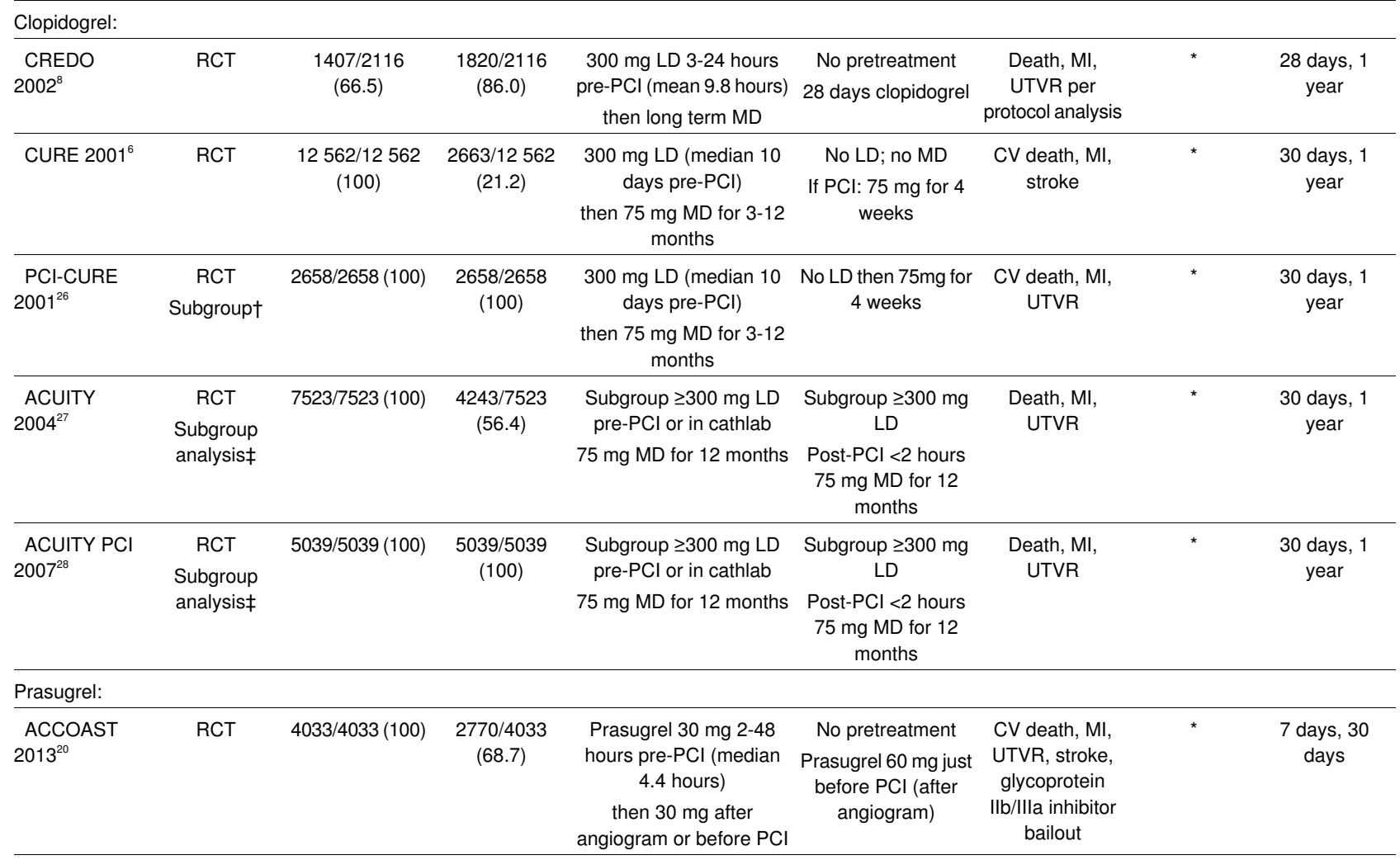

$\mathrm{ACS}=$ acute coronary syndrome. $\mathrm{PCl}=$ percutaneous coronary intervention. $\mathrm{MACE}=$ major adverse cardiovascular events. $\mathrm{MD}=\mathrm{maintenance}$ dose. $\mathrm{LD}=\mathrm{loading}$ dose. $\mathrm{Ml}=$ myocardial infarction. UTVR=urgent target vessel revascularization. $\mathrm{TIMI}=$ thrombolysis in myocardial infarction. $\mathrm{CV}=\mathrm{cardiovascular}$. cathlab=catheterization laboratory. IC=intracranial.

*Bleeding definition are TIMI major and minor definition except for CURE and PCI-CURE (major bleeding=substantially disabling bleeding, intraocular bleeding leading to loss of vision, or bleeding necessitating transfusion of $\geq 2$ units of blood) and for ACUITY and ACUITY PCI (defined as "clinically significant bleeds"). †Post-randomization subgroup defined as randomized comparison.

fObservational studies from RCT database (pre-specified non-randomized subgroup analysis of RCT). 


\section{Figures}

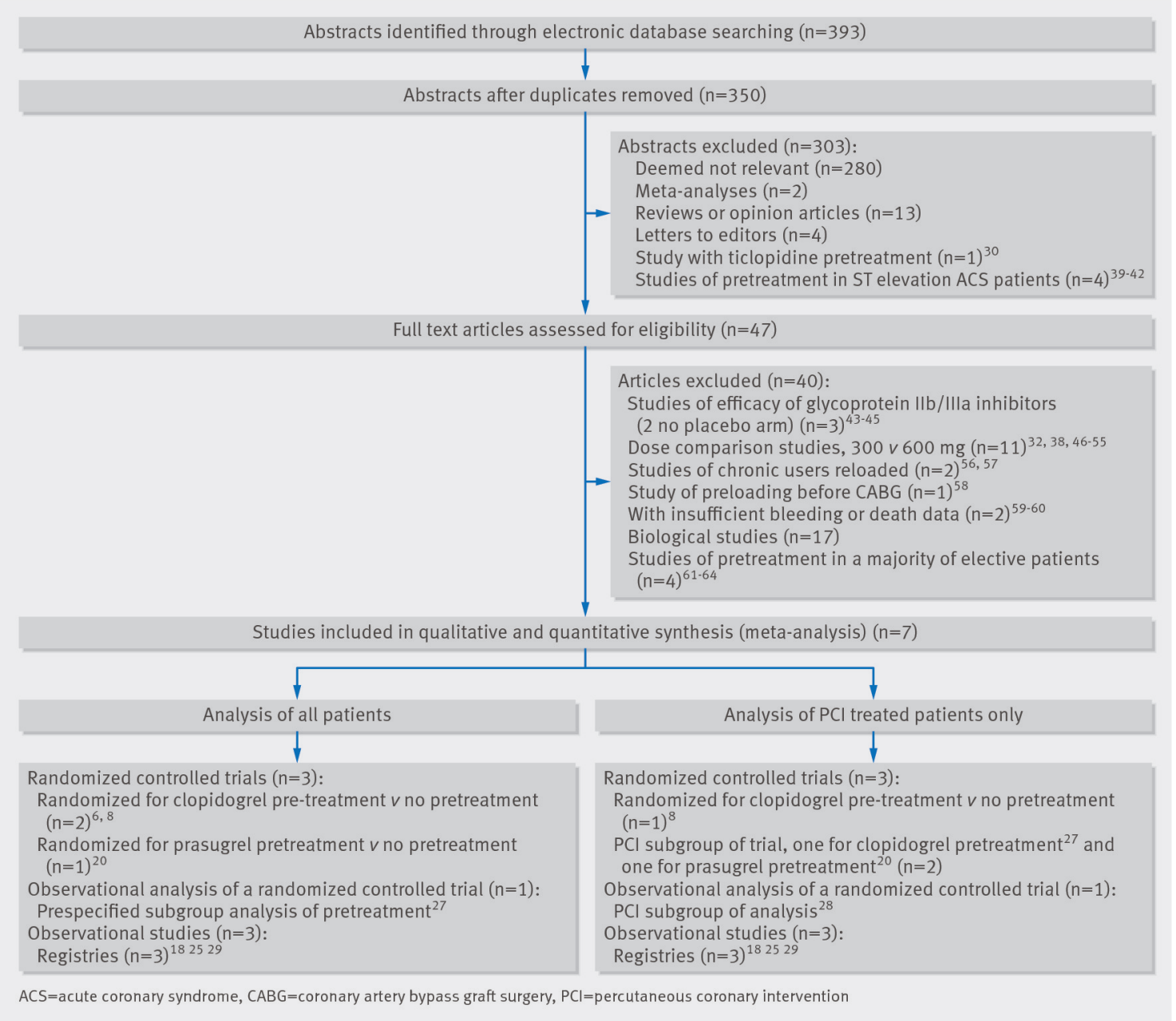

Fig 1 Flow chart of study selection 


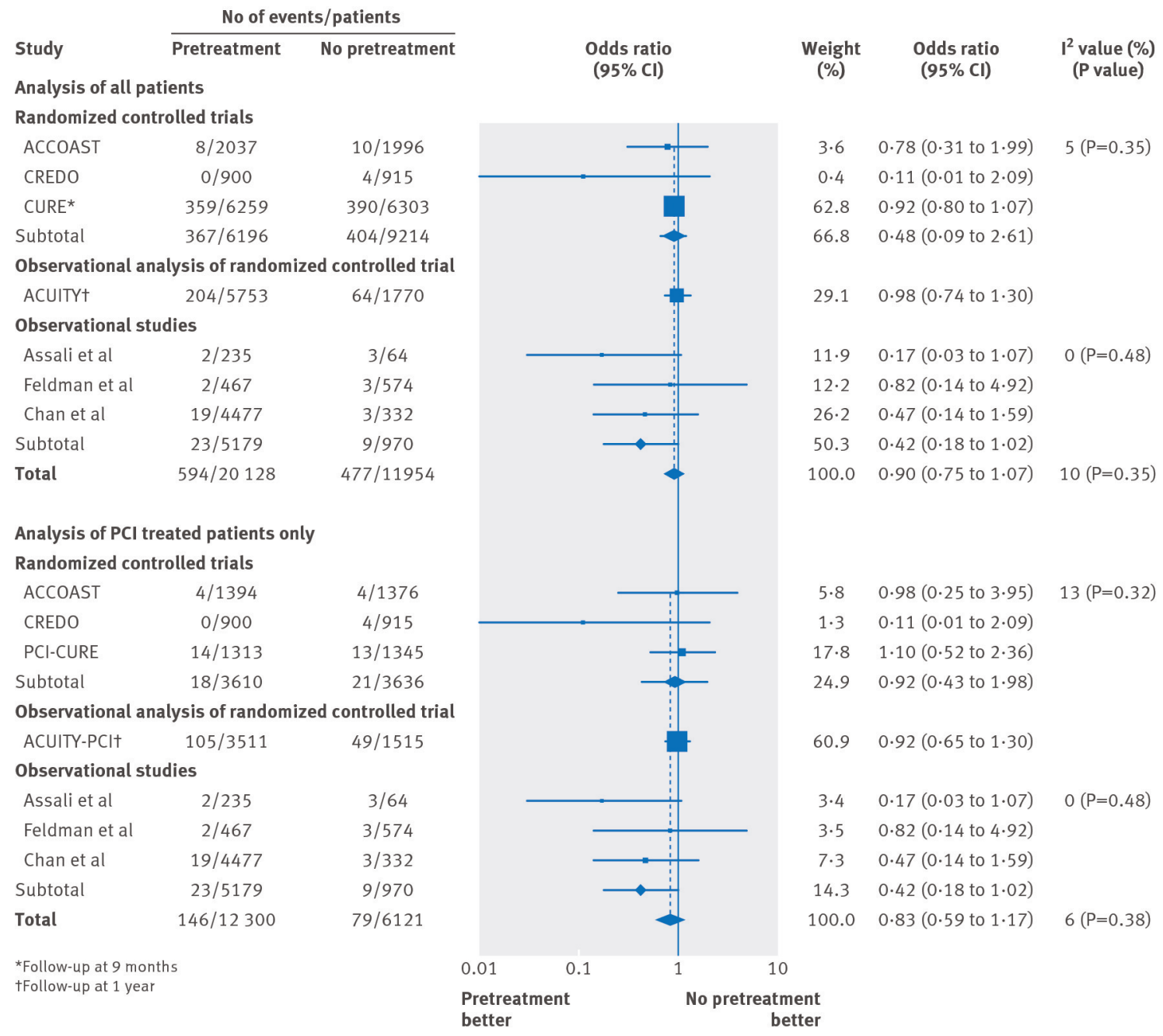

Fig 2 All cause death for all patients with non-ST elevation acute coronary syndrome (ACS) (top) and those who underwent percutaneous coronary intervention $\left(\mathrm{PCl}\right.$ ) (bottom) comparing pretreatment with $\mathrm{P}_{2} \mathrm{Y}_{12}$ inhibitors versus no pretreatment. Death was considered at shortest follow-up available in each study which was 7 or 30 days unless indicated otherwise. 


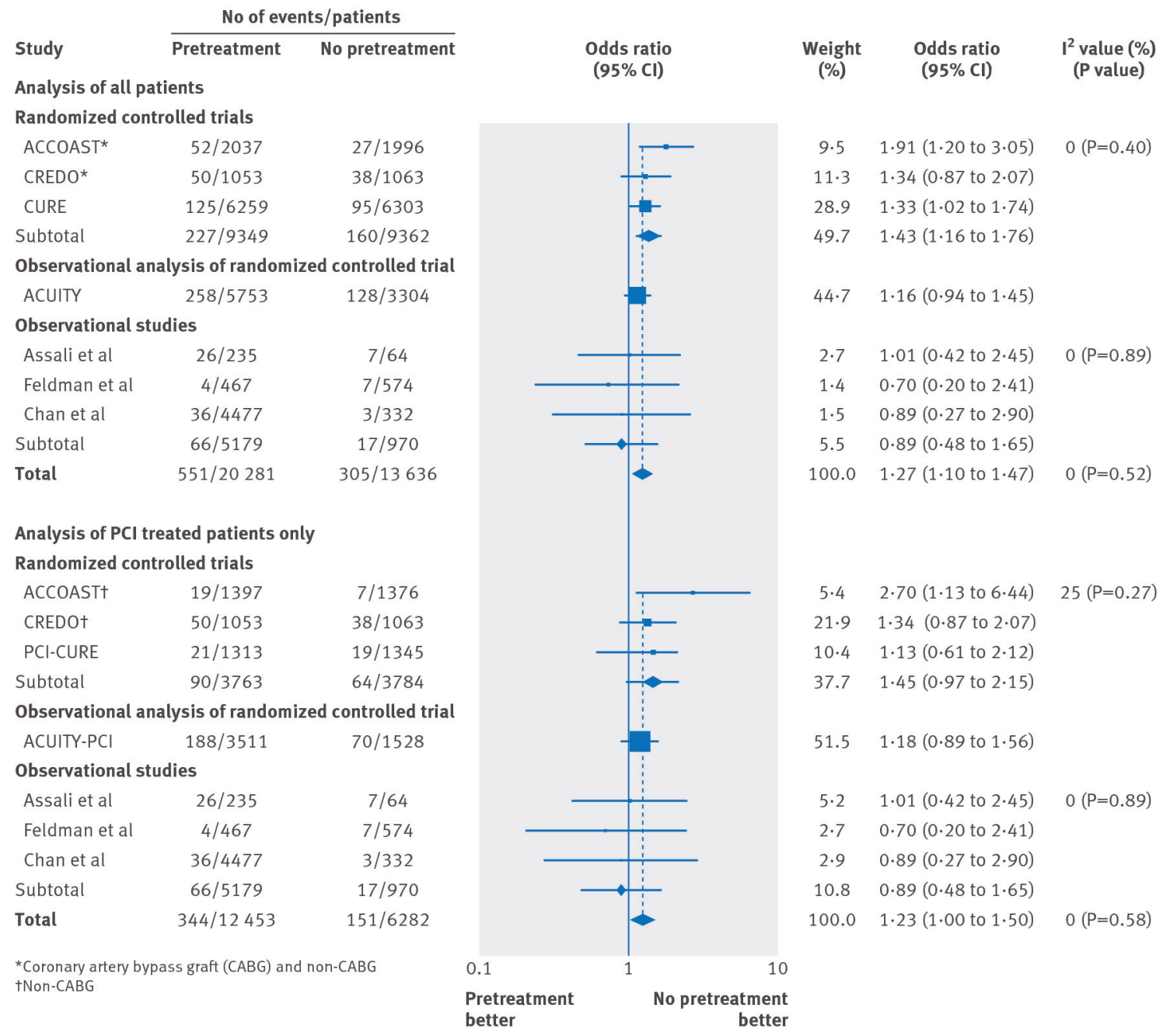

Fig 3 Major bleeding for all patients with non-ST elevation acute coronary syndrome (ACS) (top) and those who underwent percutaneous coronary intervention (PCI) (bottom) comparing pretreatment with $\mathrm{P}_{2} \mathrm{Y}_{12}$ inhibitors versus no pretreatment. Major bleeding was considered at shortest follow-up available in each study which was 7 or 30 days unless indicated otherwise 


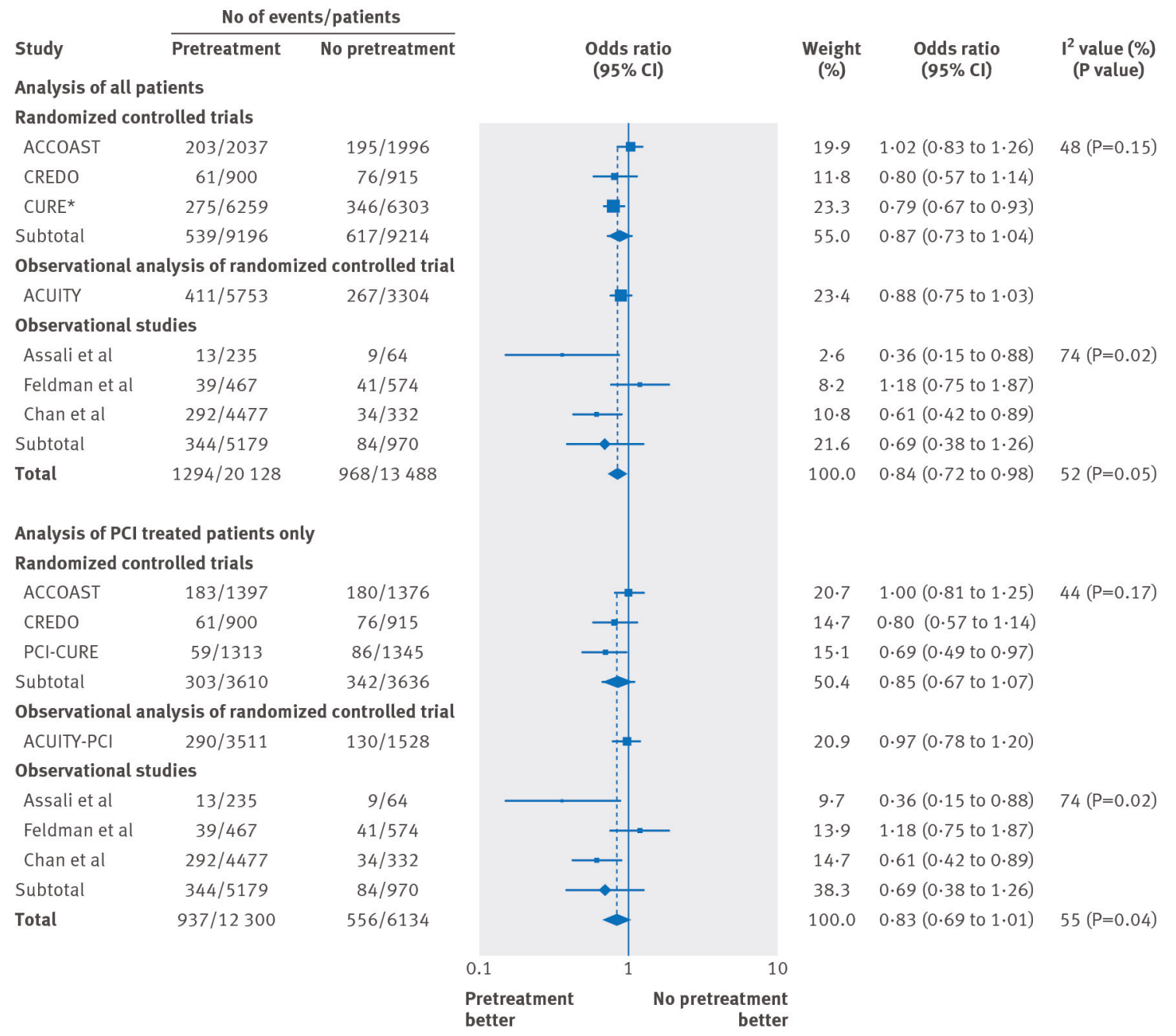

Fig 4 Main composite ischemic endpoint for all patients with non-ST elevation acute coronary syndrome (ACS) (top) and those who underwent percutaneous coronary intervention (PCI) (bottom) comparing pretreatment with $\mathrm{P}_{2} \mathrm{Y}_{12}$ inhibitors versus no pretreatment. The composite ischemic endpoint was considered at shortest follow-up available in each study which was 7 or 30 days unless indicated otherwise 


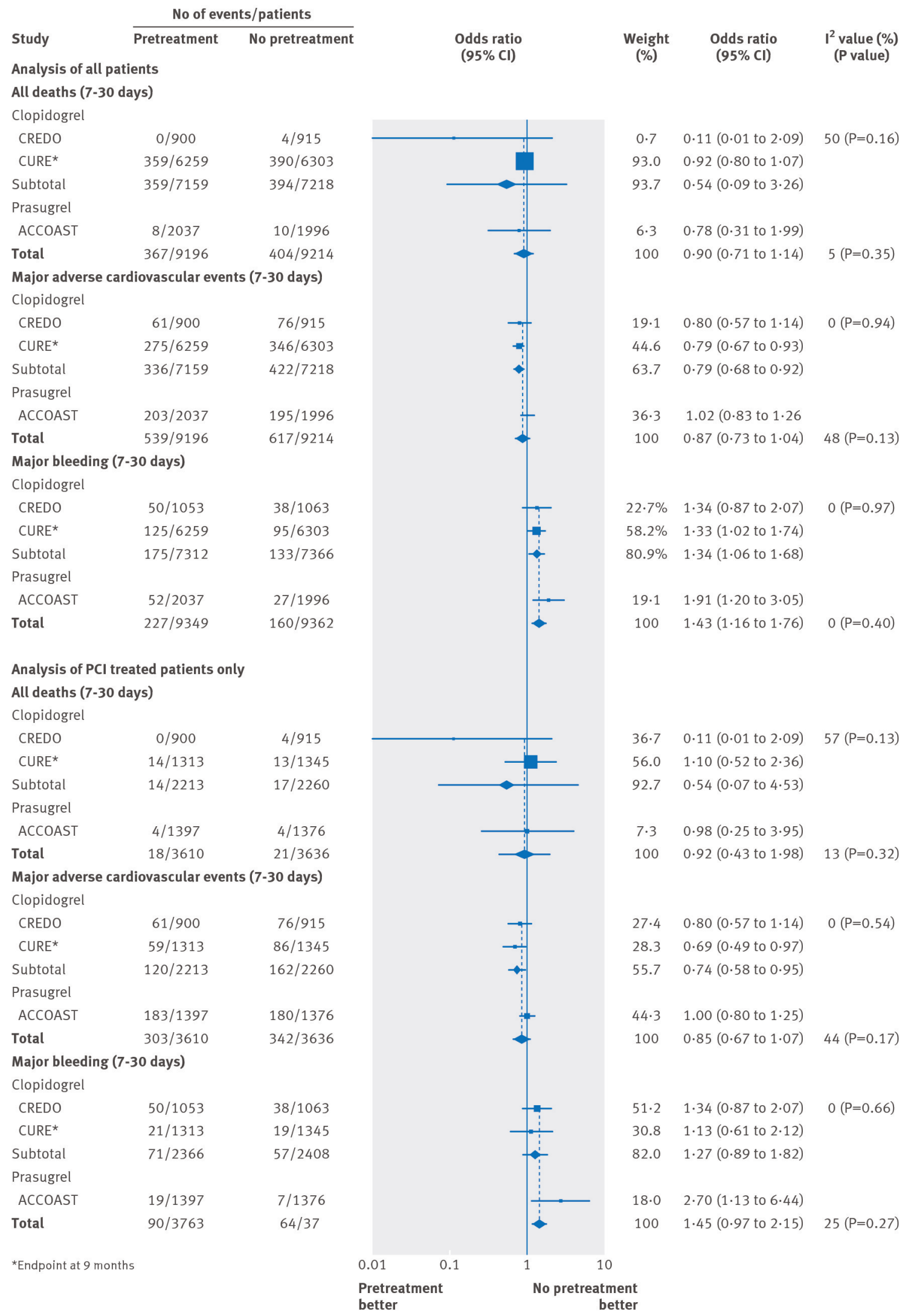

Fig 5 Main ischemic and hemorrhagic endpoints in randomized controlled trials only for all patients with non-ST elevation acute coronary syndrome (ACS) (top) and those who underwent percutaneous coronary intervention ( $\mathrm{PCl}$ ) (bottom) comparing pretreatment with $\mathrm{P}_{2} \mathrm{Y}_{12}$ inhibitors versus no pretreatment. All endpoints were considered at shortest follow-up available in each study which was 7 or 30 days unless indicated otherwise 